\title{
Informal Empire in Argentina: an Alternative View
}

\author{
A. G. HOPKINS
}

\section{Introduction}

Andrew Thompson's review of the long-running debate on informal empire will be welcomed both by specialists, who need to be reminded from time to time that many trees do sometimes make a forest, and by teachers, who need help in guiding their students through both. ${ }^{1}$ The comments that follow are therefore offered in a constructive spirit that is wholly in accord with Thompson's purpose in trying to take hold of a notoriously slippery concept. My aim in citing his work is to identify the batch of established arguments that his essay faithfully represents. The intention is to move the debate forward: the temptation to readvertise familiar positions will be avoided as far as is possible; the risk of drowning the argument in an excess of detail is removed by limitations of space.

Thompson's survey, as specialists will readily recognise, is essentially a restatement and confirmation of the series of objections made by Platt and others against both Gallagher and Robinson and advocates of the dependency thesis. ${ }^{2}$ Thompson advances his case by looking at three measures of informal imperialism: the degree of indirect power exercised by Britain; the distribution of gains between Britain and Argentina; and the role of collaborating elites. His general conclusion is that the record does not support the view that Britain succeeded in establishing an informal empire in Argentina. Before the $1870 \mathrm{os}$, Britain's influence was

1 'Informal Empire? An Exploration in the History of Anglo-Argentine Relations, I $810-1914$ ', Journal of Latin American Studies, vol. 24 (1992), pp. 419-36.

2 References to Platt and to the debate in general can be found in two valuable compilations: Wm. Roger Louis (ed.), Imperialism: The Gallagher and Robinson Controversy (New York, 1976), and Stuart Jones (ed.), Economic Interpretations of Nineteentb-Century Imperialism, special issue of the South African Journal of Economic History, vol. 7 (1992).

A. G. Hopkins in Professor of International History at the Graduate Institute of International Studies, Geneva. 
very limited and fell far short of 'indirect political hegemony'. ${ }^{3}$ Even after that date, and despite the massive expansion of her interests in the republic, Britain still did not succeed in exercising control over Argentina's economic affairs, with the result that, down to igi4, Argentina's 'autonomy had not been prejudiced'. 4 This outcome, Thompson argues, flowed from the fact that Britain did not enjoy a monopoly of trade and finance, that her influence on policy was limited, that export-expansion was not imposed but negotiated in ways that gave scope for local choice and initiative, and that international trade was mutually advantageous.

I shall begin by summarising Thompson's argument and identifying some of the difficulties raised by his three measures of informal imperialism. I shall then outline an alternative way of analysing the problem.

\section{A survey surveyed}

The question of 'indirect political hegemony'5 and its associate, 'control of Argentine economic affairs', ' has both chronological and analytical dimensions. Thompson argues that informal control of any kind was very limited before 1870 . Although there may be some room for argument about the precise date, there is currently little scope for disagreeing on the matter of substance. Platt showed that Gallagher and Robinson overemphasised the extent of British influence during this period; while his evidence stands so must his conclusion. Indeed, to labour this judgement is to push on an open door: the definitive statement on the subject was made by Charles Jones in an article published in this journal more than a decade ago.

In the second half of the century, and certainly after 1870 , the problem becomes much more complicated. All parties to the debate, including Thompson, accept that British interests, especially economic interests, expanded greatly during this period. The question is whether the process is to be viewed as being an extension of normal business activity, or whether it also delivered a degree of control that reflected inequalities in the power of the trading partners. Thompson's handling of the economic issues is insufficiently detailed (doubtless for reasons of space) to prove the case he wishes to make. His observation that 'Argentina's reliance upon one creditor engendered some instability but the effects of this are better

3 Thompson, 'Informal Empire?', p. 425.
4 Ibid., p. 430.
5 Ibid., p. 425 .
6 Ibid., p. 426.

"Charles Jones, "Business Imperialism" and Argentina, 1875-1900: A Theoretical Note', Journal of Latin American Studies, vol. 12 (1980), p. 437. Curiously, Thompson makes no reference to this article. 
seen as a series of unconsummated examples of British influence rather than a general pattern of control ${ }^{8}$ assumes that the exceptions he cites refute the hypothesis. However, the importance of the exceptions cannot be assessed until the hypothesis itself has been clearly specified. As I shall suggest later on, this requires some understanding of the aims of the dominant power in seeking to create (or control) subordinate states. Thompson's criticism of Ford's standard account of Anglo-Argentine economic relations ${ }^{9}$ refers to two of the implications of Ford's analysis but does not address his main concern, which was to show how Argentina became integrated into the international economy under the gold standard and to reveal the mechanisms that enabled the system to function. Similarly, while Thompson (following Marichal and Kuznets) concedes that 'Britain exerted some leverage over the Argentine economy, which became responsive to domestic developments within the U.K. ${ }^{10}{ }^{10}$ he goes on to suggest that neither author offers "watertight models for the pattern of overseas investment in Argentina'. "It is not clear exactly what Thompson's reference to 'watertight models' means: Marichal's assessment draws together research by previous writers to support judgements that are unexceptional rather than controversial; Kuznets's study was global in scope and was never intended to contribute to this particular debate. Thompson's main criticism appears to be less with the analysis deployed by Ford and Marichal to explain the flow of finance and goods in the international economy than with their failure, as he sees it, to give sufficient weight to conditions and initiatives in Argentina. This objection, however, is tangential rather than central: as we shall see later, the fact of dependence needs to be separated both from its consequences and from the various local inputs that helped to create or modify it.

Thompson also presents his own reasons for showing why the expansion of British interests was not accompanied by an extension of informal control. The first reason is based on the proposition that the problem is 'best illustrated by delineating the limits to Britain's economic influence in the region'. ${ }^{12}$ This assumption is open to question: in searching for the limits without either identifying the criteria for defining the existence of an informal empire or establishing what Britain's aims in Argentina were, Thompson's list of exceptions may contain examples that are unimportant to the conclusion he wishes to establish. The problem of definition is most appropriately considered in the next section of this essay; Britain's aims will be noted at this point to show how they can be used as a check on Thompson's argument.

8 Thompson, 'Informal Empire?', p. 426.
9 Ibid., p. 427 .
12 Ibid., p. 426
11 Ibid., p. 428. 
If, for example, it is argued that Britain's overriding purpose was to create the conditions needed to promote overseas investment and to maintain debt service, then her success or failure can best be judged by looking at the deals struck in areas most closely related to this aim. Thompson's procedure does not encourage us to do this. Instead, he identifies constraints that may have been irrelevant or insignificant in this context. His first illustration, ${ }^{13}$ citing competition from foreign banks, if pursued further, would show that neither France nor Germany could offer Britain serious competition in financing Argentina before 1914, and would therefore confirm the dominance of the City of London. ${ }^{14}$ The second illustration, ${ }^{15}$ the invasion of the meat-packing industry by the USA in 1907 , simply demonstrates what is generally agreed, namely that Britain favoured free trade and non-intervention in South America, and gives some of the reasons why. In addition, we might add that because Argentina was able to develop new markets overseas her export earnings could be boosted and hence too the revenues that serviced foreign loans. Thus, the diminution of Britain's influence in one area (meat packing) may have helped to maintain British interests in another (finance). To appreciate this possibility, however, it is necessary to take a view of Britain's global position and to have a clear perspective on her priorities in Argentina.

Thompson's second reason for denying that expanding interests were accompanied by expanding control is that key events in the history of Anglo-Argentine relations can be understood fully only be taking account of the periphery as well as of the metropolis, ${ }^{16}$ a point also heavily emphasised by Ferns. ${ }^{17}$ Thus, we are told that 'significantly, Marichal concedes that the debt crisis of 1890 was unleashed by the crash in the Argentine economy itself', ${ }^{18}$ that, while the 'British and Argentine economies had become enmeshed', the 'resolution of the 1890 crisis is an excellent example of how this fact had repercussions for both nations', ${ }^{19}$ and that Britain had to 'show some largess' in the debt settlement 'if she was to recover her investment and preserve a growing market for her imports', ${ }^{20}$

These observations are not as damaging as Thompson supposes. They are significant only if a restrictive (and unrealistic) definition of informal empire is adopted, one that assumes that all causation was located in the

13 Ibid., p. 426.

14 See, for example, H. S. Ferns, Britain and Argentina in the Nineteenth Century (Oxford, 1960), pp. 69, 108-9; Roger Gravil, The Anglo-Argentine Connection, 1900-1930 (Boulder, Col., 1985), Pp. 24-7; C. Marichal, A Century of Debt Crises in Latin America: From Independence to the Great Depression, 1820-1930 (Princeton, N.J., 1989), p. I6I.

15 Thompson, 'Informal Empire?', p. 427.

16 Ibid., pp. 428-9.

17 H. S. Ferns, 'The Baring Crisis Revisited', Journal of Latin American Studies, vol. 24 (1992), pp. $24 \mathrm{I}-73$.

19 Ibid., p. 429.

18 Thompson, 'Informal Empire?', p. 428.

20 Ibid., p. 429. 
metropolis, that events on the periphery had no effect on the centre, and that informal influence was the result of a series of directives that were uncontaminated by negotiation or concession. This was not Gallagher and Robinson's position in their 1953 article: indeed, as is well known, Robinson subsequently developed an 'excentric' theory of empirebuilding that emphasised the role of the periphery without in any way retreating from the concept of informal empire. ${ }^{21}$ However, there is a more important point to make here, namely that Thompson's argument rests on assumptions that, as I shall try to show later, fail to distinguish between levels of power and degrees of power. That Argentina played the best hand she could does nothing to weaken the fact that Britain dealt the cards; that some of the repercussions of international economic crises were felt in Britain as well as in Argentina shows only that there was mutual involvement, not that there was equal involvement; that Britain had to negotiate and conciliate on a range of items, just as she had to in much of the formal empire, should not be a cause of surprise once it is remembered that it was Britain, not her satellites, who set the agenda in the first place.

Thompson's next measure of informal empire relates to the distribution of the gains arising from trade and investment. Here, Thompson's case is that Argentina benefited from overseas trade and inflows of foreign capital, that the relationship between Britain and Argentina was 'mutually advantageous', ${ }^{22}$ and that export expansion of the kind experienced by Argentina, under British sponsorship, was the most promising route to economic development. ${ }^{23}$ There are two comments to be made on these propositions. The first concerns the technicalities of measuring gains from international trade. Thompson does not explore this topic and it is too complex to be entered into in the space available here, though of course it should have a place in any full account of the consequences of 'dependent development'. The second comment, which is far more important in the present context, concerns the relevance of this discussion to the idea of informal empire.

Thompson has merged two arguments: one deals with the presence or absence of informal empire; the other refers to the merits and defects of the dependency thesis. He begins his article with a clear statement of Gallagher and Robinson's thesis $;^{24}$ mid-way through he refutes the idea of informal empire by alluding to arguments put forward by the dependentistas ; $^{25}$ and by the close he refers to 'Robinson and Gallagher and

21 Ronald Robinson, 'Non-European Foundations of European Imperialism: Sketch for a Theory of Collaboration', in Roger Owen and Bob Sutcliffe (eds.), Studies in the Theory of Imperialism (London, 1972), pp. I $17^{-} 4^{0}$.

22 Thompson, 'Informal Empire?', p. 435.

24 Ibid., pp. 419-20.

23 Ibid., pp. 429-30.

25 Ibid., pp. 427, 429 . 
the dependency school' as if they can be harnessed together. ${ }^{26}$ Thompson is not alone in running these arguments in tandem, and it is easy to see why: the themes of foreign influence and dependence have a common starting point in the history of European (capitalist) expansion, and they have now merged in the historiography of Latin America to such an extent that it is very difficult to tell them apart.

Nevertheless, at the risk of disturbing some familiar patterns of thought, it is necessary to insist that, though the subjects of imperialism and dependency overlap, they are not identical. Using arguments appropriate to one to refute the other is an invalid procedure that is in no way legitimated by the frequency of its appearance. Gallagher and Robinson were concerned, above all, to establish a new way of looking at the concept of imperialism. To this end, they laid considerable stress on the role of expansionist forces stemming from Britain. But their essay was not concerned with the long-term effects of imperialist expansion on the development of the periphery, and they made no mention of the dependency thesis, even in its pre-Frankean manifestations. The dependency thesis, on the other hand, was concerned almost exclusively with the consequences of capitalist (which became virtually a synonym for imperialist) expansion. ${ }^{27}$ It took the world system as given, and accordingly was content with a highly generalised version of its origins and various forms.

Thus, when Thompson attacks the 'primary weakness in the argument of the dependentistas', ${ }^{28}$ namely that Argentina should have followed a path of development other than that routed through primary exports, he undoubtedly identifies an important line of argument, which he then pursues effectively in citing the work of Lewis and others on the relationship between railways and economic development. ${ }^{29}$ But none of this has any bearing on Gallagher and Robinson's thesis, either as stated by them, or as an inference of what their argument might have committed them to had they extended it to the developmental consequences of imperialist expansion. The logic of their position is that imperialist powers seek to maximise, or at least to pursue, their own interests. It does

26 Ibid., p. 435 .

27 I hope it will be clear that here and throughout I am referring to what 1 shall call the simple dependency thesis, which also seems to be Thompson's principal frame of reference. I am aware of the 'new dependency thesis' and other sophisticated versions, which ought to be distinguished from the popular, Frankean statement. However, the emphasis is justified in the present context because the simple version has penetrated the corpus of historians to a degree unmatched by other, inevitably more complex, offerings. For one of a number of helpful guides see Philip J. O'Brien, 'Dependency Revisited', in Christopher Abel and Colin Lewis (eds.), Latin America, Economic Imperialism and the State (1985), pp. 40-69.

28 Thompson, 'Informal Empire?', p. 429.

29 Ibid., pp. $430-4$. 
not follow, as a matter of necessity, that this purpose is incompatible with the interests of others on the periphery or that gains from imperialist expansion accrue exclusively to the metropolis. ${ }^{30}$ To defeat Andre Gunder Frank is not to bring down Gallagher and Robinson. The latter are indeed open to criticism, but scarcely by attacking them on territory that they were not concerned to occupy, still less to defend.

Thompson's third measure of informal control, the role of collaborating elites, can be dealt with briefly, not least because it occupies only a small place in his general argument. The question Thompson seeks to answer in this connection is whether Argentina's landed elite were 'intermediaries of Britain's "informal empire" or independent actors on the Argentine political stage'. ${ }^{31}$ His treatment of this subject is neither sustained nor systematic (no doubt for reasons of space), but the general tenor of his argument is to show that the Argentine elite acted in their own interests. ${ }^{32}$ Once again, it is not clear that acceptance of this conclusion is in any way damaging to the concept of informal empire. Thompson tells us, for example, that Rosas cultivated international ties from motives of enlightened self-interest: 'he was not duped or beguiled into doing so'. . $^{3}$ But this condition was never part of Gallagher and Robinson's thesis, and the main purpose of the notion of collaboration (even though we may have reservations about the term itself) was to show how like-minded elites came into prominence by pursuing interests that complemented those of the major power. It may be that Thompson is dealing here with the leakage of ideas from dependency, nationalist, or Marxist-conspiracy channels, or he may have tapped an even deeper source in theories, drawn from political science, that require a degree of compulsion to be present if the exercise of power is to be demonstrated. It has to be emphasised, however, that these are accretions or extensions that were not present in Gallagher and Robinson's original statement; nor are they necessary to the restatement that I shall now outline.

\section{A revision revised}

Perhaps the most fundamental, and certainly the most difficult, problem in the discussion of imperialism is the definition of the terms on which the whole edifice of argument and refutation stands. This observation ought to be so evident as to be redundant by now. Unfortunately, however, historians are often less than explicit in revealing the assumptions that

30 Gallagher and Robinson also allowed for the possibility of coercion as well as collaboration. In such cases, however, 'housebreaking' would be followed (in Gallagher and Robinson's view) by the creation of collaborators drawn from local elites.

31 Ibid., p. $422 . \quad 32$ Ibid., pp. 424, $430 . \quad{ }^{33}$ Ibid., p. 424. 
underpin their erudite use of source material, and indeed sometimes give the impression that assumptions are merely the ideological prejudices of those whose views they happen to disagree with. Consequently, the debate over imperialism has long been bedevilled by the obscurity of some of the basic presuppositions, with the result that wires have been crossed and inappropriate proofs offered for favoured arguments - in ways discussed in the previous part of this essay.

Imperialism involves the diminution of sovereignty through the exercise of power. ${ }^{34}$ Accordingly, an analysis of the phenomenon needs to be based on an understanding of these terms. Sovereignty can be defined as control over the key elements of statehood: the constitution, law, foreign policy and defence, education (and information), and economic development. The adequacy of this list is open to discussion (and there is certainly scope for its refinement), and there is much room for debate over various possible measures of diminishing control and hence of sovereignty itself. Ideally, these themes require at least a book, and probably a lifetime too. My purpose here is limited simply to identifying, in principle, the main elements that need to be considered.

The question of power is equally vast and probably even more resistant to agreed definition, which means that it is all the more important for historians to be explicit about the particular usage they favour. Suppose, for example, that they assume a meaning that is close to Dahl's oft-quoted definition, which stresses the element of command: power is the ability to get others to do what they would not otherwise do. ${ }^{35}$ On this assumption, actors on the periphery who were not compelled or deceived into taking decisions and actions would not, strictly speaking, be subject to the exercise of power or, by extension, to imperialism. Thus, in Thompson's example, Rosas was not duped, but acted in his own interests. However, this definition of power is limited and limiting: it describes only one possibility and excludes others, many of which, arguably, occur more widely. We might reasonably add, for instance, that power has an enabling dimension: the ability to persuade others to do what they could not do unaided, or to move more quickly than they might otherwise do if left to themselves. In this case, as I observed earlier, Rosas could act in his own interests and still be strongly influenced by external forces, including those

34 Among other things, of course. One obvious addition, worth noting at this point, is that imperialism has an integrative function. Evidently, this is not true of all cases where the exertion of external power by one state diminishes the sovereignty of another.

35 Initially in Robert A. Dahl, Who Governs? Democracy and Power in an American City (New Haven, Conn., 1961). For an urbane but also learned survey see Joseph S. Nye, 'The Changing Nature of World Power', Political Science Quarterly, vol. 10s (1990), pp. $177-92$. 
associated with imperialism. By extension, there is also a demonstrative aspect to power: the ability to influence through example. This ability attaches to a major power by virtue of the moral authority it exercises, with the result that it can alter and sometimes transform the preferences of those drawn into its orbit. ${ }^{36}$ These possibilities suggest that differences in historical interpretation can often be traced to their conceptual foundations, which need to be revealed before their strength can be assessed.

The next question is how to make the concept of power operational. Again, there are various possibilities, each with its advocates and critics. The point to stress, once more, is that what is needed is a visible framework of analysis; otherwise claims and counter-claims become lost in a vast no-man's-land between assertion and evidence. One promising approach, which I shall use here for purposes of illustration, is that set out recently by Susan Strange. ${ }^{37}$

Strange suggests that we should think of two kinds of power in international relations. The first is what she terms structural power, which allows its possessor to determine, or at least exert a predominant influence on, the range of choice open to actors in the international arena, and to lay down the general rules of the game governing relations between them. ${ }^{38}$ She identifies four main aspects of structural power: control over credit, control over production, control over security, and control of knowledge, beliefs and ideas - which correspond closely to the elements of sovereignty listed earlier. None of these exerts primacy over the others by virtue of an ex cathedra ruling; each can be the foundation of effective power, sometimes by itself, more often in combination, and with varying degrees of emphasis, with one or more of the others. Between them, they establish the framework for relations between the parties concerned. The second form of power, relational power, has received rather more attention, both from political scientists and from historians. Typically, it has been used to examine relations between interests within a given authority structure (notably the nation state) or to consider the various bargains made between states in pursuing their priorities in the international arena. As we have seen in considering the approach favoured by Dahl, care has to be taken here to define the exercise of power in ways

${ }^{36}$ Nye, 'The Changing Nature of World Power', refers to this as 'co-optive power' (p. 181).

37 Susan Strange, States and Markets (London, 1988), Ch. 2. Thompson ('Informal Empire?', p. 434, n. 38 ) also refers to this study but does not incorporate it into his analysis.

38 Specialists will have noted the difference between this use of the term structural and that favoured by neo-realists. 
that do not exclude forms of behaviour that are generally agreed to fall within the boundaries marked by the study of imperialism.

Evidently, structural and relational forms of power are closely linked: one establishes the context and the rules of the game; the other deals with contests between the players. At the same time, the importance of distinguishing between the two levels of analysis ought to be equally apparent. On the one hand, conceptions of structural power should not become simply a means of inferring or, more formally, of verifying the outcome of the key bargains made at the relational level. On the other hand, an investigation of imperialism that is confined to relational power can readily be programmed to conclude too much from too little. The first temptation has attracted advocates of the simple dependency thesis, whose assumptions about the international power structure passed directly into their understanding of relations within that structure and then came out as conclusions about the consequences of imperialism - all with a speed and certainty that was at once breathtaking and flawed in its basic assumptions, in its often cavalier use of evidence, and in its deployment of a rudimentary verificatory methodology. The second temptation has beguiled many liberal critics, who have drawn general conclusions about the validity of the notion of informal empire from their assessment of the deals struck between British and Argentine interests at the local level without first relating the various outcomes to the structural features that established the boundaries of the bargaining process. To repeat: it is of limited value to show that there were checks to Britain's influence in Argentina unless this conclusion is also related to an understanding of Britain's aims in the republic.

I shall conclude by indicating, with necessary brevity, how these rather abstract propositions can be illustrated by the history of Anglo-Argentine relations. Of the four types of structural power identified by Strange, I shall examine just one, credit, as this is generally agreed to have been particularly important to Argentina from the second half of the nineteenth century onwards. Foreign investment and credit played a key role in financing nation-building (sovereignty being a requisite for sovereign debt) and, as is well known, in developing an export economy, which was fundamental to generating the revenues that filled out the power of the state and the wealth that supported the political and personal fortunes of the ruling elite. Britain's role in this process was to integrate parts of the world that lacked adequate capital markets of their own with the City of London, which was well able to supply their needs. The essence of the contract was that the recipients should honour their debts and generally maintain a regime that was stable and sufficiently congenial in its attitude towards expatriate interests to reassure foreign investors and their 
associates. Such, in essence, was the framework of opportunity (and the accompanying rules) presented to Argentina in the nineteenth century. The package was devised and issued by Britain, not by the recipients.

It is necessary, at this point, to emphasise the obvious, not only because it remains important, but also because historians who focus on the relational aspects of power are inclined to take for granted or even to minimise broader (structural) considerations of this kind. Indeed, the tendency of analyses that focus on local bargaining is precisely to show that deals were struck by parties negotiating in the free market place of trade and investment, and in this way to suggest that there was a high degree of equality between them. ${ }^{39}$ It is therefore essential to be quite clear, even at the risk of repetition, that the context defining the options was shaped by the major power, in this case Britain. To put it at its simplest: the pattern of Argentina's development in the nineteenth century is incomprehensible unless this fact is kept centrally in mind.

Furthermore, it is evident that the relationship was also an unequal one. Liberal critics of the dependency thesis are often concerned to deny the existence of inequality because they fear making a concession that would carry them on a devil's ride through asymmetry to 'unequal exchange', 'distorted development', and on to the terminus - underdevelopment. But it is possible to buy the ticket without taking the journey. Just as inequalities in the relationship are, in principle, consistent with mutual gains, so the results of dependence are not programmed identically for all nations and all periods of time. The fact that the simple dependency thesis insisted on these connections in no way compels us to follow suit; but in rejecting the inevitability of some of the consequences, we can still accept the premise that the relationship was unequal.

The imbalance is evident in the patterns of investment and trade that accompanied the growth of the export economy. It has been estimated that approximately half of Argentina's fixed assets (excluding land) were owned by foreigners, principally the British, by $1914 ;{ }^{40}$ Argentine investors, on the other hand, held an infinitesimal share of British assets. Similarly, Argentina conducted about 28 per cent of her foreign trade (imports and exports) with Britain in $19 \mathrm{I} 3$, whereas less than 5 per cent of Britain's overseas trade was accounted for by Argentina. ${ }^{41}$ British

39 This is the focus adopted by D. C. M. Platt (ed.), Business Imperialism, 1840-1930: An Enquiry Based on British Experience in Latin America (Oxford, 1977).

40 See Alan M. Taylor, 'External Dependence, Demographic Burdens and Argentine Economic Decline After the Belle Epoque', Journal of Economic History, vol. 2 $^{2}$ (1992), pp. 907-36. 'Taylor underlines the importance of foreign capital to Argentina's economic growth by showing that the republic's economic problems in the 1920 sere closely linked to the drying up of financial flows from abroad.

41 D. M. C. Platt, Latin America and British Trade, 1806-1914 (London, 1972), p. 111. 
power was felt in Argentina in shaping the structures and policies that supported the export sector and its sustaining financial flows; Argentina's influence on the formation of Britain's governing elite and on the cast of her international policy was minimal. During the financial crises of the 18 gos there were fears in Buenos Aires that Britain might adopt formal measures of intervention $;^{42}$ no one in London lost sleep worrying about the prospect that Argentina might seek to discipline her creditors in the City. The Anglo-Argentine connection was important to Britain; it was vital to Argentina.

Within this structural framework, negotiations between the parties allowed scope for adjusting the precise terms of particular bargains, and hence for fine-tuning the division of gains (and losses). This will surprise only those who suppose that relational power consists of getting people to do things that they would not otherwise do. But, as I have already pointed out, Britain's attitude towards Argentina was based on the assumption that the most effective form of management was by selfpolicing, not by command. Argentina was regarded, with the colonies of white settlement, as being a European society overseas: once the republic had been shown the light, it was expected to follow the way in creating institutions that would give expression to individual initiatives while anchoring them in approved property rights, and would set in train a process of economic 'improvement' that would be consistent with political stability. It was recognised, of course, that Argentina differed from the white empire in a number of respects, among them its republicanism, its Catholicism, and its predominantly southern European immigrant population. Against this, there were reassuring signs of conformity as far as Britain's essential interests were concerned, and these were greatly assisted by the Anglo-centric, indeed Anglophile, connections of members of the elite, even if not all of them had been educated, like Pellegrini, at Harrow.

Since Britain's main priority in Argentina centred on finance, the crucial test, at the relational level, of her performance as the dominant foreign power is her record in defending and advancing this interest. Here the results are surely unambiguous: Britain lost nothing of real importance and made considerable gains as the period advanced. Limitations of space allow only one example, though an important one, to be cited: the Baring crisis, and the developments that followed in its wake.

The Baring crisis put to the test the alliance forged between Buenos Aires and the City of London from the 1860 , following the settlement of the defaulted debt of 1824 and the resumption of new lending to complete

42 This serves as a reminder that perceptions, and in this case misperceptions, are important to understanding outcomes. 
the unification of the republic and to generate export growth. ${ }^{43}$ One of the consequences of the export expansion that followed was the appearance of what today would be called development debt, whereby Argentina contracted fixed obligations that had to be met from variable export proceeds. At the close of the i 880 s a financial crisis, compounded by managerial errors on both sides, threatened the funding of the external debt. The crisis broke in 1890 and was eventually resolved in 1893 , after lengthy negotiations and considerable political uncertainty in Argentina, by the Romero Agreement, which established the terms of the debt settlement.

That the crisis had local manifestations, even some local causes, is not surprising. Given the extent to which Argentina had become integrated into the international economy, the surprise would be their absence rather than their presence. It is equally apparent that local initiatives played an important part, along with those of Lord Rothschild, in devising a solution to the crisis. ${ }^{44}$ However, it should also be clear that acceptance of these facts is perfectly consistent with the view that Argentina remained financially dependent upon London. Indeed, the settlement demonstrated the extent to which the prosperity and political authority of the Argentine elite rested ultimately on the power of the City ${ }^{45}$ After the fall of Juárez Celmán in 1890 successive administrations took every opportunity to proclaim their determination to conform to banking orthodoxy, and they matched their words with actions. Argentina resumed full interest payments in 1897 , one year ahead of schedule, returned to the gold standard in 1899 , and began borrowing again heavily thereafter. This reaction was fully in accord with London's judgement, which was formed in the knowledge that Argentina had no alternative sources of external capital and was managed by an elite that, like those in the white empire, could be trusted in the end to conform to the rules of the game. This was not a deal between peers: the parties had joint interests, but not equal power in pursuing them. The settlement of the Baring crisis acknowledged this fact.

The wider consequence of the settlement was to enable British firms to

43 The literature on the Baring crisis is too weighty to be listed here. Most of the important references can be found in P. J. Cain and A. G. Hopkins, British Imperialism: Innovation and Expansion, $1688-1914$ (London 1993), Chs. 4 and 9, to which should now be added Ferns, 'The Baring Crisis', cited above, n. 17.

44 Ferns, 'The Baring Crisis'.

45 That this was perfectly clear to the Argentine elite themselves is demonstrated by John E. Hodge, 'Carlos Pellegrini and the Financial Crisis of $1890^{\circ}$ ', Hispanic American Historical Review, vol. so (1970), pp. 499-\{23, Hodge, like Ferns, was concerned to emphasise the part played by members of the local elite, but he drew a different conclusion about their independence. Ferns, strangely, appears to have bypassed Hodge's work - which may help to explain its unjustified obscurity. 
penetrate further into the Argentine economy, thus accelerating a process that had started in the 1860 , when the large joint stock banks began a financial advance that gave British companies a sizeable stake in railways and public utilities, as well as in banking and insurance. ${ }^{46}$ The Baring crisis brought down two of the largest Argentine banks, and left the London and River Plate Bank in an unassailable position. As the economy revived, the London and River Plate took the lion's share of renewed business and returned impressive profits down to I9 I4. The crisis also put an end to Argentina's attempt to build a nationally owned railway network. The need to cut expenditure and generate income to meet the conditions of the debt settlement forced the government to 'privatise' parts of the railway system by selling state companies to foreign, mainly British, firms. ${ }^{47}$ Tariff policy remained equally friendly to foreign business interests, and was aimed chiefly at generating the trade and revenues needed to service the external debt and fund the administration. By i9 14 , to cite the authoritative judgement of Charles Jones, 'large sections of the Argentine economy were controlled from London'. ${ }^{48}$

\section{Conclusion}

Gallagher and Robinson were not the first scholars to make use of the idea of informal empire, but they struck at the right moment and in a highly effective way, and they succeeded, deservedly, lodging the concept in the literature. The idea itself has long been open to criticism: it was analytically imprecise and it has proved to be empirically vulnerable to specialist expertise. The analytical uncertainties have usually been glossed over by historians, which is why some attention has been paid to them here. ${ }^{49}$ The empirical criticism, on the other hand, is voluminous, but much of it makes an imponderable contribution to balancing the final account because its underlying concepts remain obscure.

46 See, for example, the important essays by Charles Jones, 'Commercial Banks' and 'Insurance Companies', in Platt, Business Imperialism, chs. I-2; idem, 'The State and Business Practice in Argentina, 1862-1914', in Abel and Lewis, Latin America, ch. 10; idem, 'Great Capitalists and the Direction of British Overseas Investment in the Late Nineteenth Century: the Case of Argentina', Business History, vol. 22 (1980); Linda Jones, Charles Jones and Robert Greenhill, 'Public Utility Companies', in Platt, Business Imperialism, ch. 3. Also V. B. Reber, British Mercantile Houses in Buenos Aires, 1810-1880 (Boston, Mass., 1979), ch. 4, and D. Joslin, A Century of Banking in Latin America (London, 1963), ch. 4.

47 See Colin Lewis, British Railways in Argentina, 1877-1914: A Case Study of Foreign Investment (London, 1983), pp. 86-7, i $18-20$; Marichal, $A$ Century of Debt, pp. 168-9.

48 Jones, 'Business Imperialism', p. 442.

49 For the exception that proves the rule see Jürgen Osterhammel, 'Semi-Colonialism and Informal Empire in Twentieth-Century China: Towards a Framework of Analysis', in Wolfgang J. Mommsen and Jürgen Osterhammel (eds.), Imperialism and After: Continuities and Discontinuities (London, 1986), ch. 19. 
The argument advanced here suggests that the concept of informal empire, like its companions, the 'semi-colonies' and the 'invisible empire', is in principle a valuable means of categorising conditions of domination and subordination whereby a major state acts as an integrative force, exercising power in ways that infringe the sovereignty of smaller countries. Whether the results of this process assist or frustrate the course of economic development is an important, but also a separate, question that should not be allowed to prejudge the prior issue of how far the recipients had become dependent upon external forces.

Regarding Argentina, I have tried to show that it is possible to take issue with the liberal critics of Gallagher and Robinson without at the same time falling into the capacious embrace of the dependency thesis. But this conclusion itself does not simply involve a reversion to the undiluted version of the original proposition advanced in 1953 . In my judgement, there is a plausible case for referring to an informal imperialism of intent that produced results in securing Britain's main financial interests in Argentina. However, much of the discussion, following Gallagher and Robinson, has tended to treat the terms imperialism and empire as if they were interchangeable, thus effectively merging them. The result is an inbuilt bias towards exaggeration - a case of what might be called scientific hyperbole, excusable in establishing the notion of informality but difficult to defend thereafter. In principle, the terms ought to be distinguished. Imperialism suggests a process whereby elements of sovereignty were being eroded; empire implies a stage of completeness comparable to the status of colonies in the formal empire. Whether informal imperialism also amounted to informal empire in Argentina is a question that can be answered only after the analysis has been extended to cover aspects of sovereignty, besides finance, listed earlier. This is an exercise that requires a book rather than an article; even so, the manuscript cannot be written until detailed research on topics such as foreign policy, defence, education and information has been completed. ${ }^{50}$ Gallagher and Robinson also argued that the high point of informal empire occurred during the midVictorian era. Subsequently, as Britain fell into relative decline as a great power, she lost ground to her rivals and was driven, for defensive reasons, into making formal acquisitions in various parts of the world. ${ }^{51}$ The

so Gallagher and Robinson may well have the last word as they had the first. On the one hand, colonial powers may not be able to exercise, in practice, the sovereignty that is formally theirs. In other words, they may need to resort to techniques of informal influence within the context of formal rule. On the other hand, it is possible for an external power to dominate, informally, the most important aspects of the sovereignty of an independent state without dominating them all and without seeking to do so.

51 This development became clear in their later work: see especially Ronald Robinson and 
argument outlined here is clearly very different: Britain's effective influence was expanding in Argentina at the very moment when it was supposed to be in general decline, and Britain herself remained a dynamic and successful imperialist power right down to I9I4.

Informal imperialism was an expanding reality in Argentina in the late nineteenth century. We may pause before accepting that the results amounted to a comprehensive informal 'empire', but the degree of subordination in the critical area of finance and credit should not be in doubt. Contemporaries were well aware of this: after Argentina failed in 1892 to secure alternative sources of finance from the United States, the US consul in Buenos Aires reported, ruefully, that the British were involved in 'everything, except politics, as intimately as though it were a British colony'. ${ }^{2}$ The consul's use of terms may have been instinctive rather than scientific, but his judgement points us in the right direction.

John Gallagher with Alice Denny, Africa and the Victorians: The Official Mind of Imperialism (London, 1961).

52 Quoted in Joseph Smith, Illusions of Confict: Anglo-American Diplomacy Towards Latin America, 1865-1896 (Pittsburgh, Pa., 1979), p. 190. 